Bangladesh J. Bot. 48(1): 195-203, 2019 (March)

\title{
GENETIC DIVERSITY IN NINE CHICKPEA (CICER ARIETINUM L.) VARIETIES BASED ON DIFFERENT MOLECULAR MARKERS
}

\author{
Kazi Nahida Begum** ${ }^{1}$ and Sheikh Shamimul Alam \\ Department of Botany, University of Dhaka, Dhaka-1000, Bangladesh \\ Keywords: Chickpea, Genetic diversity, Molecular markers
}

\begin{abstract}
Nine varieties (BARI Chola-1 to BC-9) of chickpea (Cicer arietinum L.) were studied with respect to isozymes, SDS-PAGE, amplified DNA produced by RAPD- and SSR-markers. The varieties could be characterized by SDS-PAGE bands on the basis of their location, size and intensity. Three isozyme systems, namely acid phosphatase, esterase and peroxidase were investigated of which esterase was found to be suitable for produced distinct polymorphic bands with $57.14 \%$ diversity. Ten RAPD primers were producing 74 bands with $93.24 \%$ polymorphisms which indicated highly diverse nature. In addition to polymorphism, 12 variety-specific RAPD fragments were identified. Ten SSR primer pairs were producing 20 distinct bands of which 11 were considered as polymorphic (55\%). On the basis of RAPD and SSR analysis, BC-1 and BC6 were placed in cluster- 1 and the remaining varieties were placed in cluster-2. On the other hand, the combined data of three isozymes systems and SDS-PAGE made BC- 8 and BC-9 were different and thus placed in cluster-2 while the other seven varieties were placed in cluster-1.
\end{abstract}

\section{Introduction}

Bangladesh Agricultural Research Institute (BARI) released nine varieties of Cicer arietinum L. (Mandal et al. 2011). These are characterized on the basis of their morphological features and yield production. This kind of characterization sometimes creates problem since phenotypic features are not always reliable. Successful breeding program depends on the complete knowledge and understanding of the genetic diversity within and among genetic resources of the available germplasms. This will enable plant breeders to choose parents that generate diverse populations for selection (Esmail et al. 2008).

Molecular markers are efficient tools to estimate the genetic diversity. Among the molecular markers isozymes systems and SDS-PAGE have been successfully applied for germplasm characterization (Netra and Prasad 2007). Three most widely used isozymes are acid phosphatase, esterase and peroxidase. These are being used in plants for various purposes, including taxonomic or genetic relationship studies (Iqbal et al. 2005).

DNA fingerprinting by RAPD is one of the molecular methods for characterizing germplasms. RAPD analysis is used to evaluate a diverse level of polymorphism in different crops such as chickpea 98.14\% (Rasool 2013), chickpea 87\% (Datta et al. 2010), Brassica 98.03\% (Ghosh et al. 2009), eggplant 57.89\% (Biswas et al. 2009), peanut 96\% (Lang and Hang 2007), peanut 42.7\% (Raina et al. 2001) and chilli 90\% (Paran et al. 1998).

Simple sequence repeats (SSRs) are another class of molecular microsatellite marker based on tandem repeats of short (2 - 6 bp) DNA sequences (Litt and Lutty 1989). These repeat sequences are often highly polymorphic, even among closely related varieties. Due to the slippage mutations during DNA replication causing variation in the number of repeating units. SSR markers are generally reported to detect higher levels of polymorphism and to provide the molecular differentiation to facilitate routine diversity analysis and molecular breeding applications (Russel et al. 1997, Crouch et al. 1999).

*Author for correspondence: <kazinahida@yahoo.com>. ${ }^{1}$ Department of Botany, Jagannath University, Dhaka-1100, Bangladesh. 
Although some molecular marker analyses of chickpea have been undertaken earlier, these were scattered and not exactly used for characterization. No attempt has been made earlier to analyze different molecular data for characterizing chickpea varieties. In the present study, different types molecular analysis viz. isozyme, SDS-PAGE, RAPD and SSR were carried out for the first time to characterize nine chickpea varieties released from BARI with a view to evaluating the genetic diversity and the phylogenetic relationship.

\section{Materials and Methods}

The seeds of nine varieties of chickpea (Cicer arietinum $\mathrm{L}$.) viz. BC-1 (BARI Chola-1), BC-2, BC-3, BC-4, BC-5, BC-6, BC-7, BC-8 and BC-9 obtained from the Pulse Research Center (PRC), BARI were grown in the field of the Botanical garden, Department of Botany, University of Dhaka.

The young leaves were collected from the field and homogenized in cold distilled water in an ice cold mortar pastel with liquid nitrogen and centrifuged at $4^{\circ} \mathrm{C}$ using $12000 \mathrm{rpm}$ for $10 \mathrm{~min}$. Supernatant was discarded and pellet used for isozyme and SDS-PAGE experiment. A mixture of $50 \mathrm{ml}$ was freshly prepared by the following proportion of $49 \mathrm{ml}$ of $\mathrm{Na}_{2} \mathrm{CO}_{3}(1 \%), 0.5 \mathrm{ml}$ of $\mathrm{CuSO}_{4}(1 \%)$ and $0.5 \mathrm{ml}$ of $\mathrm{Na}-\mathrm{K}$ titrate $(2 \%)$. The quantity of proteins in various extracts was estimated following Lowery et al. (1951). Fifteen test tubes were marked as A, B, C, D, E, F and 1 to 9. These tubes contained materials in the following proportion: tube A: $1 \mathrm{ml}$ of distilled water (control), tube B: $200 \mathrm{ml}$ Bovine Serum Albumin (BSA) with $800 \mathrm{ml}$ distilled water, tube C: 400 $\mathrm{ml}$ BSA with $600 \mathrm{ml}$ distilled water, tube D: $600 \mathrm{ml} \mathrm{BSA}$ with $400 \mathrm{ml}$ distilled water, tube E: 800 $\mathrm{ml}$ BSA with $200 \mathrm{ml}$ distilled water, tube F: $1 \mathrm{ml} \mathrm{BSA}$, tubes 1 to 9 (samples): $20 \mathrm{ml}$ extract with $980 \mathrm{ml}$ distilled water. Five $\mathrm{ml}$ of above mixture and $0.5 \mathrm{ml}$ of $50 \%$ Folin-Ciocalteu's Phenol reagent were added to each test tube and kept for $30 \mathrm{~m}$. Then spectrophotometer reading was taken for standard and sample by a spectrophotometer (UV-120-02). Three isoenzyme systems (namely esterase, acid phosphatase and peroxidase) and SDS-PAGE were used in the present investigation. These experiments were carried out following the method of Arüs and Orton (1983) and Laemmli (1970) on a Biorad Protean II system, respectively. Three separate methods of staining were used to detect the enzyme activity on the gels and SDS-PAGE methods of staining used for protein profiling. Before loading, the samples were diluted to the ratio of $2: 1$ with the sample buffer. Gel was run at $60 \mathrm{~V}$ until the tracking dye reached the separating gel and then at $200 \mathrm{~V}$ for $4 \mathrm{hrs}$. Sample containing $200 \mu \mathrm{g}$ of proteins was loaded in the gel. After running, the gel was stained by different methods for 3 different types of enzyme localization. The banded gels were photographed quickly with 8 mega pixels canon power shot A720 model.

Leaves were harvested and total genomic DNA was extracted by using modified CTAB method (Doyle and Doyle 1987). DNA concentration was quantified through spectrophotometer (Analylikjena, Specord 50, Germany).

The PCR reaction mixture for $25 \mu \mathrm{l}$ containing template DNA (25 ng) $2 \mu \mathrm{l}$, de-ionized distilled water $18.8 \mu \mathrm{l}$, Taq buffer A $10 \times$ (Tris with $\left.15 \mathrm{mM} \mathrm{MgCl}_{2}\right) 2.5 \mu \mathrm{l}$, primer $(10 \mu \mathrm{M}) 1.0 \mu \mathrm{l}$, dNTPs $(2.5 \mathrm{mM}) 0.5 \mu \mathrm{l}$ and Taq DNA polymerase $(5 \mathrm{U} / \mu \mathrm{l}) 0.2 \mu \mathrm{l}$. The PCR amplification was done in an oil-free thermal cycler (Biometra UNOII, Germany) for 46 cycles after initial denature $94^{\circ} \mathrm{C}$ for $5 \mathrm{~min}$, denature at $94^{\circ} \mathrm{C}$ for $1 \mathrm{~min}$, annealing at $34-36^{\circ} \mathrm{C}$ for $30 \mathrm{sec}$, extension at $72^{\circ} \mathrm{C}$ for $3 \mathrm{~min}$ and final extension at $72^{\circ} \mathrm{C}$ for $5 \mathrm{~min}$. In the present study, 10 oligonucleotide primers and 10 microsatellite primer pairs were used for RAPD and SSR assay, respectively (Tables 1,2).

The amplified products were separated electrophoretically on $1 \%$ agarose gel. The gel was prepared using $1.0 \mathrm{~g}$ agarose powder containing $10 \mu \mathrm{l}$ ethidium bromide $(10 \mathrm{mg} / \mathrm{ml})$ and $100 \mathrm{ml}$ $1 \times \mathrm{TAE}$ buffer at $50 \mathrm{~V}$ and $100 \mathrm{~mA}$ for $1.0 \mathrm{~h}$. Ladder DNA of $1 \mathrm{~kb}$ and $100 \mathrm{bp}$ were 
electrophoresed alongside the RAPD and SSR product as marker, respectively. DNA bands were observed on UV-transilluminator and photographed by a gel documentation system. The PCR products were analyzed after gel electrophoresis. The photographs were critically discussed on the basis of presence (1) or absence (0), size of bands and overall polymorphism of bands. These were carried out for further investigation. The scores obtained using all parameters such as isozyme, SDS-PAGE, RAPD- and SSR- analysis were then pooled for constructing a single data matrix. This was used for estimating polymorphic loci, Nei's (1972) gene diversity, genetic distance (D) and constructing a UPGMA (Unweighted Pair Group Method of Arithmetic Means) dendrogram among the specimen using the computer program "POPGENE32" (Version 1.32) (Yeh et al. 1999).

\section{Results and Discussion}

Seven bands were found in esterase system. Besides common bands, a few specific bands were found in these varieties with esterase. Band number $1(R f$ value 0.243$)$ was present in all samples except BC-8. On the other hand, band number 2 of BC- 8 was much bigger than the other band with $R f$ value 0.326 (Fig. 1A). This band (band number 2) in BC-2 was the thinnest among nine varieties. Therefore, esterase banding profile showed distinct polymorphism among nine varieties. In contrast, no significant polymorphism was found in acid phosphatase and peroxidase banding profile (Fig. 1A). Sarker and Haque (1996) observed similar pattern in esterase and peroxidase systems. Therefore, activities of esterase would be a useful tool for characterizing chickpea varieties.

A total number of 12 high molecular weight polypeptide bands were observed among nine varieties in SDS-PAGE. The position of each band tagged through labeling (Fig. 1A, Table 3). The low molecular weight bands were not reproducible, therefore not considered in the study. Although most of the bands were common in these varieties, three were polymorphic ( $R f$ value $0.099,0.275$ and 0.507 ) revealing $25 \%$ (3 out of 12 ) polymorphism. The varieties also differed in respect of banding intensity. Band number 6 and 7 were much darker in BC-2 and BC-6, respectively. The band number 7 of $\mathrm{BC}-8$ was so thick that could be easily isolated from the same band of different varieties. In addition, band number 9 was only present in BC-2, BC-6, BC-8 and BC-9 (Fig. 1A). Parker et al. (1998) had mentioned that SDS-PAGE was a powerful tool in studying population genetics. Since storage proteins (seed proteins) are not affected by environmental fluctuation, many workers used SDS-PAGE profiling technology as a reliable tool for authentic characterization of germplasm. Moreover, Jha and Ohri (1996) reported SDS-PAGE patterns as promising tool for distinguishing varieties of particular species. In contrast, other workers reported that variety identification was not possible with the SDS-PAGE method (Ahmad and Slinkard 1992, De Vries 1996). In this investigation, it was possible to characterize some chickpea varieties with SDS-PAGE protein markers and thus became a reliable tool for chickpea diversity study.

In this study, the variation among the chickpea varieties was assessed with RAPD markers. In total 35 primers were tested. Only ten RAPD primers were selected because they revealed multiband fingerprinting which were easily scorable and reproducible. A total of 74 DNA fragments were amplified with an average of 7.4 fragments per primer. Band size ranging from 250 to 10,000 bp of PCR amplification products scored for all primers (Fig. 1B, Table 1). Among the ten primers OPA-8 and primer-2 produced the highest number (10) of polymorphic bands (Fig. 1B). In contrast, the primer-23 generated the least number (4) of polymorphic bands (Fig. 1, Table 1B). Different light and bright bands were observed where light bands produced from low homology between the primer and the pairing site on the DNA strand (Thormann et al. 1994). Out 
of the total 74 amplified fragments, only 5 were common and the remaining 69 (93.24\%) were polymorphic indicating high level of diversification (Table 3). Several workers carried out RAPD analysis on chickpea. Rasool (2013) and Datta et al. (2010) found 98.14 and 87.00\% polymorphism in chickpea genotypes, respectively. In contrast, only $14.56 \%$ polymorphic products with 10 polymorphic primers were observed among 29 elite chickpea varieties by Sant et al. (1999). Moreover, Sonnante et al. (1997) observed 25.5\% polymorphic products among six chickpea accessions using 16 polymorphic primers. These results revealed that chickpea genotypes showed both high and low level of polymorphism. High level and low level RAPD polymorphisms suggested a wide range of diversification existing among different genotypes of chickpea. This information would be useful for improved breeding program of chickpea.

Table 1. List of RAPD markers generated from ten primers in nine varieties of Cicer arietinum $\mathbf{L}$. (Source: Macrogen Incorporation Korea).

\begin{tabular}{|c|c|c|c|c|c|c|}
\hline $\begin{array}{l}\text { Primer } \\
\text { codes }\end{array}$ & $\begin{array}{l}\text { Sequences } \\
\left(5^{\prime}-3^{\prime}\right)\end{array}$ & $\begin{array}{l}\text { No. of } \\
\text { total } \\
\text { bands }\end{array}$ & $\begin{array}{l}\text { Size ranges } \\
\text { (bp) }\end{array}$ & $\begin{array}{l}\text { No. of } \\
\text { common } \\
\text { bands }\end{array}$ & $\begin{array}{c}\text { No. of } \\
\text { polymor- } \\
\text { phic bands }\end{array}$ & $\begin{array}{l}\text { Number and size of } \\
\text { unique bands (bp) }\end{array}$ \\
\hline OPA-1 & CAG GCC CTT C & 7 & $500-10000$ & 0 & 7 & -- \\
\hline OPA-3 & AGT CAG CCA C & 5 & $1100-5000$ & 1 & 4 & BC-1 (2500) \\
\hline OPA-4 & AAT CGG GCT G & 9 & $500-3000$ & 0 & 9 & $\begin{array}{l}\text { BC-1 }(2500,2200,800, \\
625)\end{array}$ \\
\hline OPA-5 & AGG GGT CTT G & 8 & $1100-4000$ & 0 & 8 & $\begin{array}{l}\text { BC-1 (2000), BC-4 } \\
(4000), \text { BC-7 (1700, } \\
1300)\end{array}$ \\
\hline OPA-7 & GAA ACG GGT G & 10 & $750-4000$ & 0 & 10 & $\begin{array}{l}\text { BC-1 (1600), BC-6 } \\
(2000), \text { BC-9 }(4500)\end{array}$ \\
\hline OPA-8 & GTG ACG TAG G & 10 & $250-4000$ & 0 & 10 & -- \\
\hline Primer-2 & GTT GCG ATC C & 6 & $625-3000$ & 0 & 6 & -- \\
\hline Primer-12 & GTA TGG GGC T & 8 & $500-3000$ & 4 & 4 & -- \\
\hline Primer-19 & GAT GAC CGC C & 7 & $1500-4000$ & 0 & 7 & -- \\
\hline Primer-23 & GTC AGG GCA A & 4 & $500-2000$ & 0 & 4 & -- \\
\hline Total & Ten primers & 74 & $250-10000$ & 5 & 69 & 12 \\
\hline
\end{tabular}

In addition to polymorphism, 12 unique RAPD fragments were identified in nine chickpea varieties using ten different primer combinations. The term unique sequence means that the sequence found in a variety with a certain primer was absent in other varieties (Fig. 1B, Table 2). The unique bands were stable and specific for the respective varieties and thus could be used as a tool for characterization. In the earlier literature, there was no information about unique band except Rasool (2013) and Datta et al. (2010). The earlier authors considered all bands as polymorphic band. The unique band has a number of potential applications including the determination of variety purity, identification of mislabeled accessions and the establishment of property rights (plant variety protection and patenting).

Ten SSR primer pairs were used in this study. Each primer generated well-defined and reproducible polymorphic bands. The primer sequence, band size and banding pattern of nine chickpea varieties are presented in Table 2 and in Fig. 1C. The size of band ranged from 20 to 380 


\section{A: ISOZYMES and SDS-PAGE}

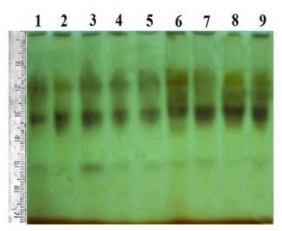

Acid phosphatase

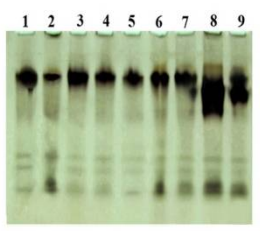

Esterase

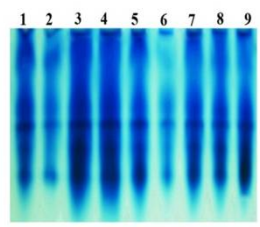

Peroxidase

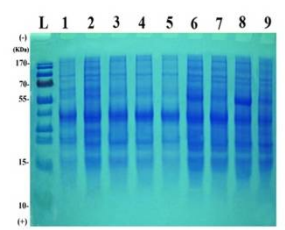

SDS-PAGE

\section{B: RAPD Profile}

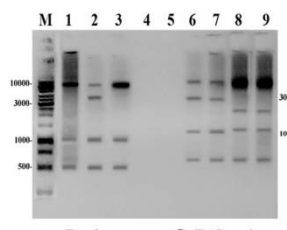

Primer OPA-1

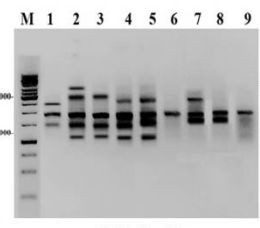

OPA-3

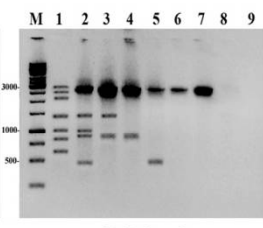

OPA-4

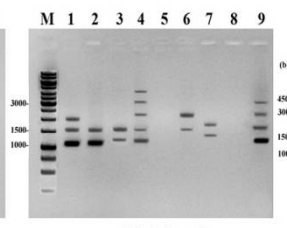

OPA-5

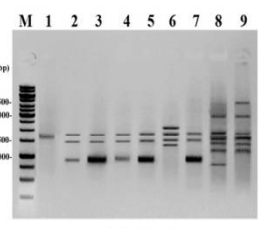

OPA-7

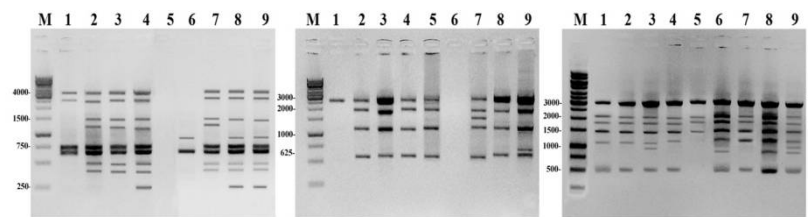

OPA-8

Primer-2

Primer-12

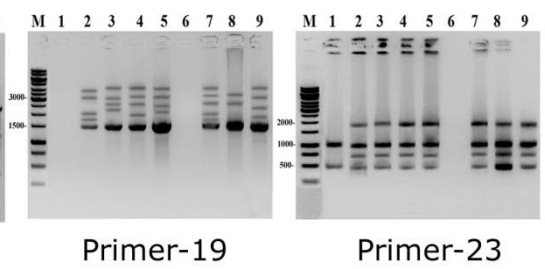

\section{C: SSR Profile}

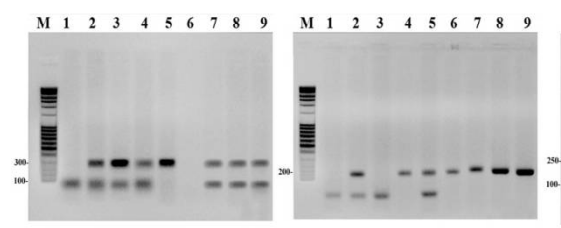

Primer GA26 CICER
CASTMS2

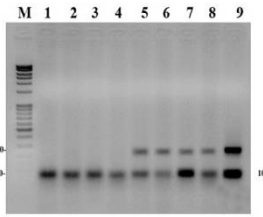

CASTMS15

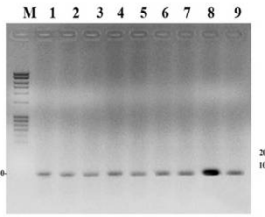

CASTMS21

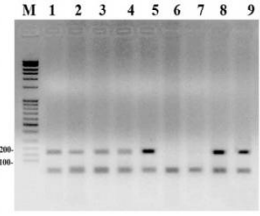

TA71

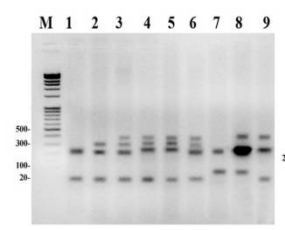

TA72

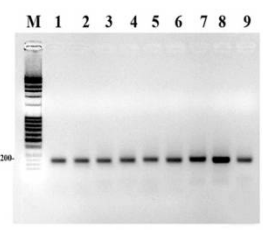

TA130

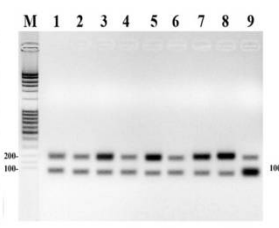

TA135

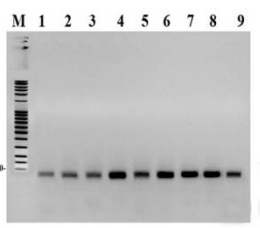

TR29

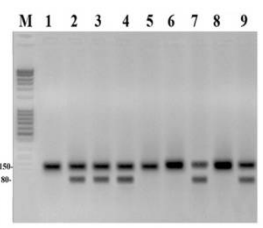

TA118

Fig. 1. Diversity in chickpea varieties based on isozyme activity, SDS-PAGE protein profile and amplified DNA profile generated by sets of RAPD and SSR primers. A: ISOZYMES and SDS-PAGE, B: RAPD profile, C: SSR profile. Chickpea varieties are marked as 1 to 9 in each gel. L and M are protein and DNA marker lanes, respectively. 
bp (Table 2). Out of ten, the primer pair TA72 produced highest number (4) of polymorphic bands while the primer pair CASTMS21, TA130, TA135 and TR29 did not generate any polymorphic band (Fig. 1C, Table 2). In total, ten primer pairs produced 20 distinct bands of which 11 were considered as polymorphic and thus showed moderate level of polymorphisms (55\%) (Table 3). Datta et al. (2010) studied 93\% average polymorphism among chickpea and pigeonpea genotypes. Like RAPD, a wide range of SSR polymorphism indicated broad diversity within chickpea varieties.

Table 2. SSR markers generated from ten primer pairs in nine varieties of Cicer arietinum L. (Source: Macrogen Incorporation Korea).

\begin{tabular}{|c|c|c|c|c|c|}
\hline Primer codes & $\begin{array}{l}\text { Sequences } \\
\left(5^{\prime}-3^{\prime}\right)\end{array}$ & $\begin{array}{c}\text { No. of } \\
\text { total } \\
\text { bands }\end{array}$ & $\begin{array}{l}\text { Size } \\
\text { ranges } \\
(\mathrm{bp})\end{array}$ & $\begin{array}{l}\text { No. of } \\
\text { common } \\
\text { bands }\end{array}$ & $\begin{array}{l}\text { Polymor- } \\
\text { phic bands }\end{array}$ \\
\hline GA26 CICER & $\begin{array}{l}\text { F-GTGCAGAGCATCATGCGATGCTCAAG } \\
\text { ACATCT GCCA } \\
\text { R-TCATACTCAACAAATTCATTTCCC }\end{array}$ & 2 & $80-300$ & 0 & 2 \\
\hline CASTMS2 & $\begin{array}{l}\text { F-ATTTTACTTTACTACTTTTTTCCTTTC } \\
\text { R-AATAAATGGAGTGTAAATTTCATGTA }\end{array}$ & 2 & $50-200$ & 0 & 2 \\
\hline CASTMS15 & $\begin{array}{l}\text { F-CTTGTGAATTCATATTTACTTATAGAT } \\
\text { R-ATCCGTAATTTAAGGTAGGTTAAAATA }\end{array}$ & 2 & $70-250$ & 1 & 1 \\
\hline CASTMS21 & $\begin{array}{l}\text { F- CTACAGTCTTTTGTTCTTCTAGCTT } \\
\text { R-ATATTTTTTAAGAGGCTTTTGGTAG }\end{array}$ & 1 & $80-100$ & 1 & 0 \\
\hline TA71 & $\begin{array}{l}\text { F- CGATTTAACACAAAACACAAA } \\
\text { R- CCTATCCATTGTCATCTCGT }\end{array}$ & 2 & $50-175$ & 1 & 1 \\
\hline TA72 & $\begin{array}{l}\text { F-GAAAGATTTAAAAGATTTTCCACGTTA } \\
\text { R-TTAGAAGCATATTGTTGGGATAAGAGT }\end{array}$ & 5 & $20-380$ & 1 & 4 \\
\hline TA130 & $\begin{array}{l}\text { F- TCTTTCTTTGCTTCCAATGT } \\
\text { R- GTAAATCCCACGAGAAATCAA }\end{array}$ & 1 & $170-200$ & 1 & 0 \\
\hline TA135 & $\begin{array}{l}\text { F- TGGTTGGAAATTGATGTTTT } \\
\text { R- GTGGTGTGAGCATAATTCAA }\end{array}$ & 2 & $80-200$ & 2 & 0 \\
\hline TR29 & $\begin{array}{l}\text { F-GCCCACTGAAAAATAAAAAG } \\
\text { R- ATTTGAACCTCAAGTTCTCG }\end{array}$ & 1 & $50-60$ & 1 & 0 \\
\hline TA118 & $\begin{array}{l}\text { F-ACAAGTCACATGTGTTCTCAATA } \\
\text { R-GGAAAGGTTAAGAAATTTTACAATAC }\end{array}$ & 2 & $40-140$ & 1 & 1 \\
\hline Total & Ten primer pairs & 20 & $20-380$ & 9 & 11 \\
\hline
\end{tabular}

Table 3. Comparative banding pattern obtained from different molecular methods.

\begin{tabular}{lcccc}
\hline $\begin{array}{l}\text { Molecular } \\
\text { methods }\end{array}$ & $\begin{array}{c}\text { No. of } \\
\text { total bands }\end{array}$ & $\begin{array}{c}\text { No. of common } \\
\text { Bands }\end{array}$ & $\begin{array}{c}\text { No. of polymorphic } \\
\text { bands }\end{array}$ & Polymorphism (\%) \\
\hline Isozymes & 14 & 6 & 8 & 57.14 \\
SDS-PAGE & 12 & 9 & 3 & 25.00 \\
RAPD & 74 & 5 & 69 & 93.24 \\
SSR & 20 & 9 & 11 & 55.00 \\
\hline
\end{tabular}

The values of pair-wise Nei's (1972) genetic distances analyzed by using computer software "popgene32" among nine varieties of chickpea were computed. The combined data of three isozyme systems and SDS-PAGE made BC-8 and BC-9 distinct and thus placed in cluster $2\left(\mathrm{C}_{2}\right)$ with 0.0392 genetic distance (Fig. 2a). The cluster made from RAPD- and SSR-marker analysis 


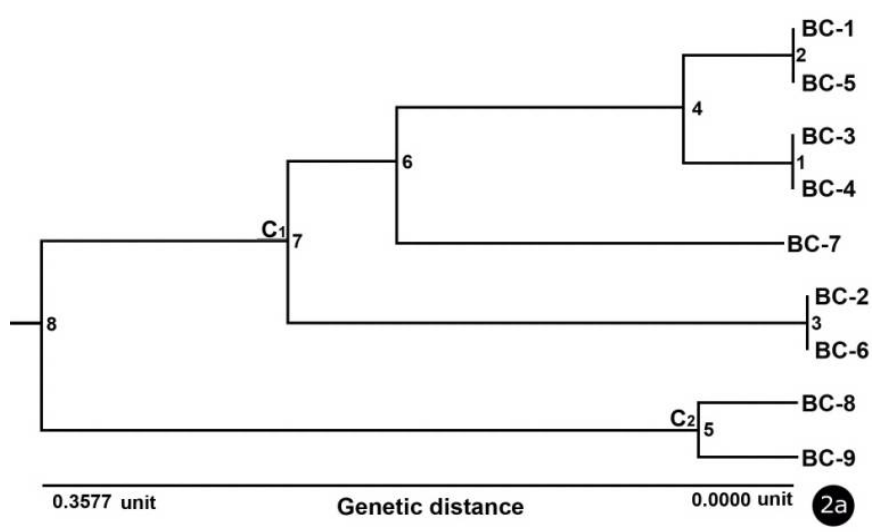

Fig. 2a. UPGMA dendrogram based on Nei's (1972) genetic distance summarizing the data on differentiation among nine varieties of Cicer arietinum L. by three isozyme systems and SDS-PAGE data analysis.

placed $\mathrm{BC}-1$ and $\mathrm{BC}-6$ in cluster $1\left(\mathrm{C}_{1}\right)$ with 0.4658 genetic distance. The lowest genetic distance was found in $\mathrm{BC}-2$ and $\mathrm{BC}-3(0.1366)$ while $\mathrm{BC}-8$ and $\mathrm{BC}-9$ showed second lowest genetic distance (0.1738) thus made sub cluster $\mathrm{C}_{2.1}$ and $\mathrm{C}_{2.2}$, respectively (Fig. 2b).

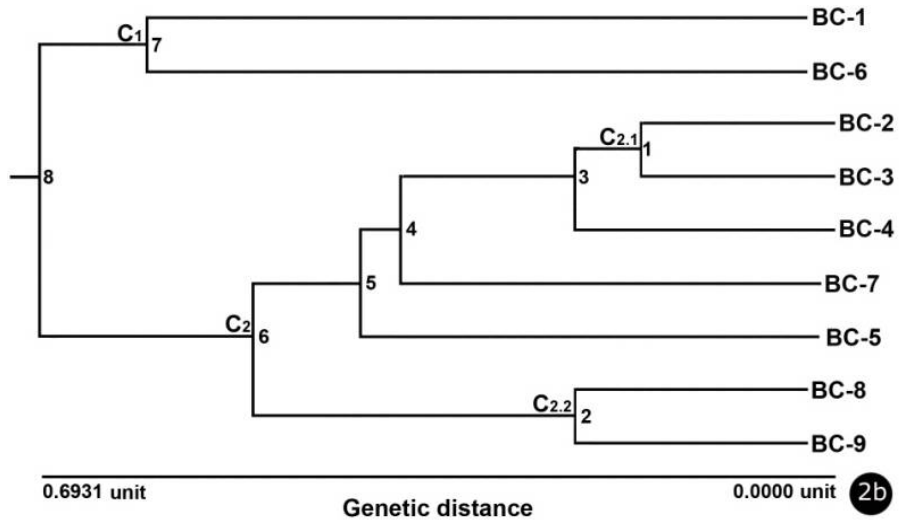

Fig. 2b. UPGMA dendrogram based on Nei's (1972) genetic distance summarizing the data on differentiation among nine varieties of Cicer arietinum L. by RAPD and SSR marker data analysis.

The difference between the highest and the lowest value of genetic distance revealed the wide range of variability persisting among the nine chickpea varieties. High genetic distance values between variety pairs were found due to difference in genetic constituent (Thormann et al. 1994). The varieties of lowest genetic distance can be used as parental source for breeding line to improve chickpea varieties.

The varieties BC-8 and BC-9 were distinct from the other seven chickpea varieties in various morphological and agronomical aspects. Among nine varieties only $\mathrm{BC}-8$ showed white color flower whereas other eight showed pink color flower. Seed coat color of BC-8 was also white. Seed size of BC-8 and BC-9 was larger than other seven varieties. These two varieties were highly disease resistant and their production rate was also higher than other chickpea varieties (Mandal et al. 2011). According to isozymes and SDS-PAGE protein profiling analysis, varieties BC-8 and 
BC-9 were different from other seven varieties and the dendrogram placed these two varieties in separate cluster (Fig. 2a). In contrast, according to RAPD and SSR-fingerprinting analysis, BC-1 and BC- 6 were distant from other seven varieties and placed in separate cluster and variety BC- 8 and BC-9 were closely related with 7 varieties and placed in sub-cluster $\mathrm{C}_{2.2}$ (Fig. $2 \mathrm{~b}$ ). Therefore, it has been possible to determine the genetic diversity among nine chickpea varieties based on isozymes, SDS-PAGE, RAPD and SSR analysis.

\section{Acknowledgements}

The first author (KNB) is grateful to the Ministry of Science and Technology, Govt. of the People's Republic of Bangladesh for the "Bangabandhu Scholarship on Science and Technology (Ph.D. category)". Thanks are due to Jagannath University, for study leave during the research period and to the Plant Breeding and Biotechnology Laboratory, Department of Botany, University of Dhaka for laboratory facilities during the work.

\section{References}

Ahmad F and Slinkard AE 1992. Genetic relationships in the genus Cicer L. as revealed by polyacrylamide gel electrophoresis of seed storage proteins. Theor. Appl. Genet. 84: 688-692.

Arus P and Orton TJ 1983. Inheritance and linkage relationships of isozyme loci in Brassica oleracea. J. Hered. 74: 405-412.

Biswas MS, Akhond AAY, Alamin M, Khatun M and Kabir MR 2009. Genetic relationship among ten promising eggplant varieties using RAPD markers. Plant Tiss. Cul. Biotech. 19(2): 119-126.

Crouch JH, Crouch HK, Constandt H, Cysel VA, Breyne P, Montagu VM, Jarret RI and Ortiz R 1999. Comparison of PCR-based molecular marker analyses of Musa breeding populations. Mol. Breed. 5: 233-244.

Datta J, Lal N, Kaashyap M and Gupta PP 2010. Efficiency of three PCR based marker systems for detecting DNA polymorphism in Cicer arietinum L. and Cajanus cajan L. Millspaugh. Genet. Engin. Biotech. 5: $1-15$.

De-Vries IM 1996. Characterisation and identification of Lactuca sativa cultivars and wild relatives with SDS-electrophoresis (Lactuca sect. Lactuca, Compositae). Grace. 43: 193-202.

Doyle JJ and Doyle JL 1987. A rapid DNA isolation procedure from small quantities of fresh leaf tissues. Phytochem. Bull. 19: 11-15.

Esmail RM, Zhang JF and Abdel-Hamid AM 2008. Genetic diversity in elite cotton germplasm lines using field performance and RAPD markers. World J. Agri. Sci. 4(3): 369-375.

Ghosh KK, Huque ME, Parvin MS, Akhter F and Rahim MM 2009. Genetic diversity analysis in Brassica varieties through RAPD marker. Bangladesh J. Agri. Res. 34(3): 493-503.

Iqbal SH, Ghafoor A and Ayub N 2005. Relationship between SDS-PAGE markers and Ascochyta blight in chickpea. Pakistan J. Bot. 37: 87-96.

Jha SS and Ohri D 1996. Phylogenetic relationships of Cajanus cajan L. Millsp. (pigeonpea) and its wild relatives based on seed protein profiles. Grace 43: 275-281.

Laemmli UK 1970. Cleavage of structural proteins during the assembly of head of Bacteriophage T4. Nature 227: 680-685.

Lang NT and Hang PTC 2007. Genetic divergence analysis on peanut by RAPDs. Omonrice 15: 174-178.

Litt M and Lutty JA 1989. A hypervariable microsatellite revealed by in vitro amplification of dinucleotide repeat within the cardiac muscle actin gene. Amer. J. Human Genet. 44: 397-401.

Lowrey OH, Rosebrough NJ, Farr AL and Randall RJ 1951. Protein measurement with the Follin-Phenol reagent. J. Biol. Chem. 193: 256-261.

Mandal MRI, Islam MS, Bhuiya MAZ, Rahman MM, Alam MS and Rahman MHH 2011. Krishi prajukti handboi, BARI udbhabito krishi prajuktir bibarani, BARI 1: 1-488. 
Nei M 1972. Genetic distance between populations. American Nat. 106: 283-292.

Netra N and Prasad S 2007. Identification of rice hybrids and their parental lines based on seed, seedling characters, chemical tests and gel electrophoresis of total soluble seed proteins. Seed Science and Technology 35: 176-186.

Paran I, Aftergoot E and Shifriss C 1998. Variation in Capsicum annuum revealed by RAPD and AFLP markers. Euphytica 99: 167-173.

Parker PG, Snow AA, Schug MD, Booton GC and Fuerst PA 1998. What molecules can tell us about populations: choosing and using a molecular marker. Ecology 79: 361-382.

Raina SN, Rani V, Kijima T, Ogihara Y, Singh KP and Devarumath RM 2001. RAPD and ISSR fingerprints as useful genetic markers for analysis of genetic diversity, varietal identification and phylogentic relationships in peanut (Arachis hypogaea) cultivar and wild species. Genome 44(5): 763-72.

Rasool S 2013. Genetic diversity as revealed by RAPD analysis among chickpea genotypes. Pakistan J. Bot. 45(3): 829-834.

Russell JR, Fuller JD, Macaulay M, Hatz BG, Jahoor A, Powell W and Waugh R 1997. Direct comparison of levels of genetic variation among barley accessions detected by RFLPs, AFLPs, SSRs and RAPDs. Theor. Appl. Genet. 95: 714-722.

Sant VJ, Patankar AG, Sarode ND, Mhase LB, Sainani MN, Deshmukh RB, Ranjekar PK and Gupta VS 1999. Potential of DNA markers in detecting divergence and in analysing heterosis in Indian elite chickpea cultivars. Theor. App. Genet. 98: 1217-25.

Sarker RH and Haque MK 1996. Study of isozyme markers in characterizing jute germplasm. Bangladesh J. Bot. 25: 139-145.

Sonnante G, Marangi A, Venora G and Pignone D 1997. Using RAPD markers to investigate genetic variation in chickpea. Journal of Genetics and Breeding 51: 303-307.

Thormann CE, Ferreira ME, Camargo LEA, Tivang JG and Osborn TC 1994. Comparison of RFLP and RAPD markers for estimating genetic relationships within and among Cruciferous species. Theor. Appl. Genet. 88: 973-980.

Yeh FC, Yang RC and Boyle T 1999. POPGENE Version 1.32: Microsoft Window-based free software for population genetic analysis. http://www.ualberta.ca/fy.ch.

(Manuscript received on 22 February, 2018; revised on 6 August, 2018) 